\title{
Pengaruh Model Pembelajaran ROPES (Review, Overview, Presentation, Exercise, Summary) Terhadap Keaktifan dan Prestasi Belajar Siswa Fisika
}

\author{
Vinsensius Man Un ${ }^{1 *}$, Muhammad Nur Hudha ${ }^{1}$, Kurriawan Budi Pranata ${ }^{1}$ \\ ${ }^{1}$ Program Studi Fisika, Universitas Kanjuruhan, Malang, Indonesia \\ *e-mail korespondensi: mantvincent@gmail.com \\ (masuk: 20-05-2020; revisi: 16-06-2020; diterima: 22-06-2020)
}

\begin{abstract}
Abstrak: Tujuan penelitian ini untuk mengetahui pengaruh model pembelajaran ROPES terhadap keaktifan dan prestasi belajar siswa fisika kelas VII di SMP PGRI 6 Malang dan mengetahui adanya interaksi antara model pembelajaran ROPES dengan keaktifan dan prestasi belajar siswa. Populasi dalam penelitian ini merupakan semua siswa kelas VII SMP PGRI 6 Malang. Teknik penentuan sampel menggunakan simple random sampling, di peroleh kelas VII B sebagai kelas eksperimen dan kelas VII D sebagai kelas kontrol. Metode penelitiannya merupakan Quasi Experimental Design. Rancangan penelitian pada penelitian ini mengunakan pretest - post-test control group design. Data keaktifan dikumpulkan melalui observasi dan data prestasi dikumpulkan melalui tes. Data yang terkumpul dianalisis dengan uji anova dua jalur dengan menggunakan bantuan program SPSS 16. Hasil penelitian menunjukkan adanya perbedaan keaktifan dan prestasi belajar siswa yang menggunakan pembelajaran model ROPES dengan siswa yang pembelajaran model konvensional. Hal ini diperkuat oleh nilai keaktifan dan prestasi yang lebih tinggi dengan model pembelajaran ROPES dibandingkan dengan model pembelajaran konvensional. Hasil penelitian juga menunjukkan adanya interaksi antara model ROPES terhadap keaktifan dan prestasi belajar siswa. Dengan demikian, dapat diambil simpulan bahwa model pembelajaran ROPES lebih berpengaruh terhadap keaktifan dan prestasi belajar siswa.
\end{abstract}

Kata kunci: keaktifan belajar fisika, model pembelajaran ropes, prestasi belajar

\section{PENDAHULUAN}

Ilmu Pengetahuan Alam (IPA) merupakan salah satu mata pelajaran mengenai alam sekitar yang dalam cakupannya berkaitan erat dengan mengetahui seisi alam secara keseluruhan secara sistematis. Salah satu mata pelajaran yang ada merupakan fisika. Fisika mempelajari tentang alam yang bisa mengembangkan daya nalar, analisis, dan pemecahan masalah.

Prestasi belajar siswa adalah cara yang bisa digunakan untuk mengetahui sejauh mana siswa dapat memahami mata pelajaran yang diterima dari pendidik serta memecahkan masalah. Siswa perlu belajar dan terlibat dalam pembelajaran untuk memperoleh prestasi yang baik. Siswa membutuhkan bantuan agar terlibat pada pembelajaran (Eggen \& Kauchak, 2012).

Dalam pembelajaran, pendidik harus mampu mengarahkan dan membimbing siswa secara maksimal (Anam, 2015). Pertama, siswa dan guru harus saling membangun komunikasi yang baik saat pembelajaran. Kedua, guru harus mampu menentukan model pembelajaran yang tepat sehingga mampu mencapai tujuan pembelajaran. Model pembelajaran adalah salah satu bentuk bantuan bagi siswa untuk belajar (Rusman, 2014). Jika pemahaman konsep dan prinsip fisika pada tingkat awal (SMP) rendah dan disertai dengan sikap negatif yang sangat tinggi 
maka sulit untuk siswa mampu berhasil dengan baik pada pembelajaran fisika pada tingkat pendidikan selanjutnya (Nurhadi, 2004).

Pembelajaran ROPES adalah bentuk pembelajaran yang dapat mengubah dan menekankan pada kemampuan bernalar dan keaktifan siswa dalam mempelajari pelajaran melalui beberapa rangkaian yang utuh dan berkaitan satu dengan yang lainnya. Berdasarkan Wahyuni (2006) dan Sinaga \& Simarmata (2014), tahapan pembelajaran ROPES yakni siswa diukur kesiapannya dalam menerima pelajaran secara bertahap pada tahap review dan meningkatkan hubungan siswa dengan bahan ajar yang akan diajarkan oleh pendidik dan memotivasi siswa untuk belajar pada fase selanjutnya melalui kegiatan overview. Siswa melaporkan hasil praktikum melalui kegiatan presentation, melakukan latihan soal pada tahap exercise, kemudian pada tahap akhir menyimpulkan materi pelajaran melalui tahapan summary.

Keaktifan pada penelitian ini dapat diartikan sebagai suatu proses pembelajaran yang dilakukan siswa dalam satu kegiatan yang dapat menciptakan situasi pembelajaran yang lebih aktif, dan pengukurannya dapat dilihat melalui nilai siswa dalam lembar observasi keaktifan siswa dengan beberapa indikator. Keaktifan siswa saat proses kegiatan pembelajaran bisa dilihat pada indikatorindikator berikut: (a) aktif memperhatikan guru selama proses pembelajaran berlangsung, (b) aktif dalam mengidentifikasi masalah, (c) aktif bekerja sama dalam kelompok, (d) aktif mencatat materi pelajaran (e) aktif mendengarkan sajian presentasi, (f) aktif mengemukakan pendapat. Keaktifan belajar fisika merupakan kegiatan belajar fisika yang bertujuan untuk memahami materi pembelajaran fisika dan memperoleh prestasi belajar fisika. Keaktifan setiap kegiatan siswa mengikuti proses pembelajaran, yakni keaktifan bertanya, menjawab, serta keaktifan dalam bekerja kelompok.

Prestasi belajar fisika merupakan kemampuan menguasai pengetahuan berupa konsep fisika dan keterampilan yang dimiliki siswa yang setelah mengalami proses belajar. Prestasi belajar ditunjukkan dengan nilai tes melalui proses pengukuran yang dilakukan pada suatu keadaan tertentu (Sudjana, 2011). Tes berupa pertanyaan yang disusun dalam bentuk uraian didasarkan taksonomi Bloom mulai dari C1, C2, C3, C4, C5, dan C6.

Sesuai dengan beberapa uraian di atas maka dapat dirumuskan tujuan pada penelitian ini yaitu mengetahui pengaruh pembelajaran model ROPES dalam meningkatkan keaktifan belajar fisika siswa, mengetahui pengaruh pembelajaran model ropes dalam meningkatkan prestasi belajar siswa dan mengetahui interaksi pembelajaran model ropes dalam keaktifan dan prestasi belajar siswa.

\section{METODE PENELITIAN}

Penelitian yang dilakukan menggunakan pendekatan kuantitatif jenis eksperimen. Rancangan penelitian pada penelitian ini adalah pretest - post-test control design (Sugiyono, 2010). Rancangan ini berarti memberikan tes kepada kelas eksperimen dan kelas kontrol yang dilaksanakan sebelum dan sesudah perlakuan.

Siswa VII SMP PGRI 6 MALANG merupakan populasi dalam penelitian ini, dengan sampel kelas VIIb dan kelas VIId. Kelas VIIb sebanyak 24 peserta sebagai kelas eksperimen dan kelas VIId sebanyak 25 siswa sebagai kelas kontrol. Pengambilan sampel melalui cara simple random sampling. Penelitian ini dilakukan di semester ganjil tahun pelajaran $2019 / 2020$.

Instrumen penelitian berupa lembar observasi untuk memperoleh data keaktifan siswa dan instrumen tes untuk memperoleh nilai prestasi belajar siswa. Validitas isi instrumen dilakukan oleh dosen pembimbing dan guru di sekolah. Hasil validasi diuji menggunakan rumus 
Pearson Product Moment dan didapatkan $r_{\text {hitung }}=0,69\left(r_{\text {tabel }}=0,159 ; \alpha=5 \%\right)$ dan reliabilitas soal menggunakan rumus korelasi alpha diperoleh $r_{11}=12,91\left(\left(r_{\text {tabel }}\right.\right.$ $=0,159 ; \alpha=5 \%$ ) (Arikunto, 2012).

Data keaktifan dan prestasi belajar telah memenuhi uji normalitas dengan uji Lilliefors taraf signifikansi 5\% dan uji homogenitas juga dengan uji Bartlett (Syaiful, 2005). Setelah penelitian semua data dikumpulkan, dan selanjutnya untuk menjawab hipotesis yang ada data harus terlebih dahulu dianalisis sesuai tujuan yang ada. Dalam proses analisis data dalam penelitian kali ini menggunakan uji anova dua jalur (two way anova) dengan taraf signifikan 5\% atau menggunakan program SPSS 16 dengan nilai 0,05 untuk menguji perbedaan kelas eksperimen dan kelas control dengan kriteria pengambilan keputusan dengan taraf signifikan 5\%, sehingga jika signifikan $<0,05$, maka $\mathrm{Ha}$ diterima dan $\mathrm{H} 0$ ditolak.

\section{HASIL DAN PEMBAHASAN Keaktifan Belajar Siswa}

Data keaktifan belajar siswa didapat dari data observasi. Adapun nilai deskripsi keaktifan belajar siswa dapat disajikan pada Gambar 1.

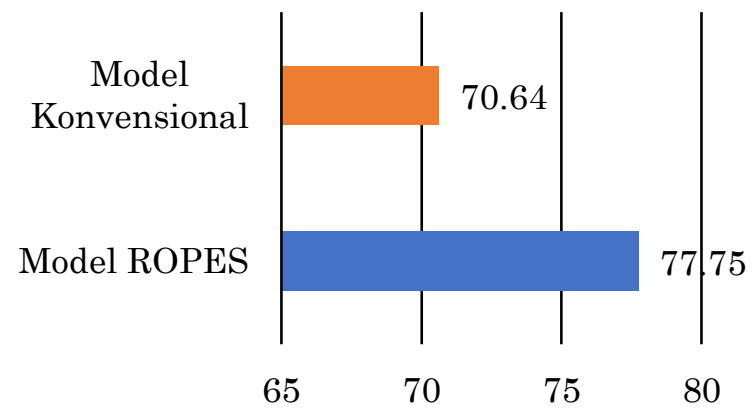

Gambar 1. Nilai keaktifan belajar siswa model ROPES dan kelas kontrol

Grafik 1 memperlihatkan bahwa rata-rata nilai keaktifan siswa kelas model ROPES adalah 77,75 pada keseluruhan semua aspek dan untuk siswa kelas model konvensional adalah 70,64. Dengan demikian, kriteria ketuntasan keaktifan belajar siswa untuk pembelajaran model ROPES nilainya lebih tinggi daripada pembelajaran dengan model konvensional untuk semua indikator keaktifan.

Hasil analisis ini untuk mencari perbedaan prestasi belajar siswa dan keaktifan belajar siswa fisika kelas VII yang dalam pembelajaran menggunakan model pembelajaran ROPES dengan pembelajaran model konvensional. Analisis ini dilakukan dengan menghitung perbedaan keaktifan belajar siswa untuk kelas kontrol dan kelas eksperimen. Uji hipotesis yanng dilakukan menggunakan two way anova berbantuan program SPSS 16. Berdassarkan nilai uji two-way anova diperoleh nilai signifikan $0,03<0,05$. Hal ini menunjukan adanya perbedan keaktifan belajar siswa baik menggunakan pembelajaran model ROPES dengan pembelajaran modeel konvensional di SMP PGRI 6 Malang.

Pembelajaraan model ROPES dapat memberi ruang cukup luas untuk siswa mengungkapkan pendapat dan bertanya atas simulasi yang disajikan oleh guru (Wahyuni, 2006; Sinaga \& Simarmata. 2014). Langkah pertama pembelajaran ROPES adalah memberikan materi secara umum. Siswa dapat melakukan simulasi menggunakan cara siswa masing-masing. Simulasi dapat dilakukan melalui inisiatif dan ide dari siswa, hal ini yang meningkatkan keaktifan belajar siswa. Hal ini berbeda dengan kelas model pembelajaran konvensional yaitu guru selalu aktif berbicara dan hasilnya keaktifan siswa untuk pembelajaran menurun. Aspek ini terlihat dari perilaku siswa yang kurang mengamati guru ketika proses belajar mengajar berlangsung.

Siswa kurang tekun ketika diberikan tugas oleh guru untuk dikerjakan, dan terlihat cepat bosan dengan pembelajaran yang konvensional. Siswa yang sudah memiliki perhatian dan minat pada pembelajaran, maka di saat guru memberikan tugas, lembar diskusi maupun ulangan harian, didapat siswa tekun mengerjakannya (Sholikhah, 2016; Faizi, 2013). Karena dengan model pembelajaran yang menarik dan kreatif, siswa merasa tidak akan bosan mengerjakan sebuah permasalahan yang 
diberikan guru, karena masalah yang diberikan memiliki banyak solusi dalam memecahkannya (Slameto, 2010; Suprijono, 2010).

\section{Prestasi Belajar Siswa}

Sesuai dengan data deskriptif prestasi belajar siswa yang didapat dari nilai post-test setelah perlakuan model pembelajaran, rata-rata dengan nilai data prestasi kelas experiment 78.54 dan kelas control 70.60. Adapun hasil deskripsi statistik analisis siswa dapat disajikan pada Gambar 2:

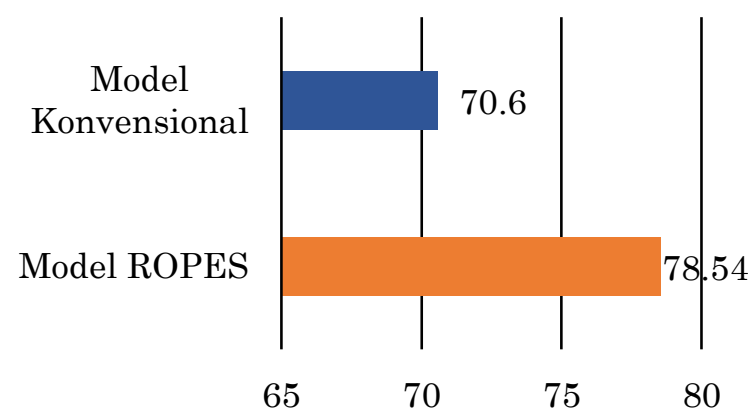

Gambar 2. Nilai prestasi belajar siswa model ROPES dan kelas kontrol

Gambar 2 memperlihatkan bahwa nilai rerata prestasi belajar siswa berdasarkan pembelajaran model bahwa prestasi kelas eksperimen sebesar 78.54 lebih tinggi dibandingkan dengan kelas control yang sebesar 70.60. Hal ini menunjukan bahwa kriteria ketuntasan untuk nilai prestasi siswa model pembelajaran ropes diatas dibandingkan dengan model pembelajaran konvensional.

Dari grafik di atas, diperoleh besarnya rata-rata nilai siswa prestasi belajar untuk kelas experimen and kelas control adalah sebesar 10. Merujuk pada data yang diperoleh diketahui bahwa nilai prestasi belajar siswa kelas eksperimen lebih tinggi jika dibandingkan dengan nilai prestasi belajar siswa kelas kontrol. Data hasil analisis untuk mencari perbedaan prestasi belajar siswa dengan yang diajarkan dengan pembelajaran model Ropes dengan pembelajaran model konvensional. Analisis ini dilakukan dengan menghitung perbedaan nilai prestasi siswa untuk kedua kelas yakni kelas experimen dan kelas control. Uji hipotesis yang dilakukan menggunakan Two-Way Anova berbantuan program SPSS 16. Sesuai dengan hasil two way anova dengan berbantuan program SPSS nilai signifikansi diperoleh $0.029<0,05$ degan demikian menunjukan hipotecis bahwa ada perbedan keaktifan dan prestasi belajar siswa baik pembelajaran model ropes maupun dengan pembelajaran model konvensional siswa di SMP PGRI 6 Malang.

Pembelajaran pada kelas eksperimen dengan pembelajaran model ROPES, dapat mengeksplorasi kemampuan bertanya siswa dan mengungkapkan pendapat terhadap pembelajaran dan simulasi yang disajikan oleh guru. Peneliti membimbing siswa dalam memecahkan masalah dengan cara yang kreatif, sesuai model pembelajaran yang digunakan dan siswa dapat memahaminya. Dibuktikan pemahaman siswa saat diberi kesempatan dari peneliti di LKS untuk dikerjakan. Saat siswa mengerjakan tugas di LKS, siswa memiliki minat untuk mengerjakan dengan teman kelompoknya, minat yang ada karena dilihat bahwa masalah yang didapat berupa masalah yang kreatif, dimana masalah yang diberikan peneliti di dalam LKS dapat menimbulkan banyak solusi. Pada tahap diskusi, saat peneliti membimbing ke dalam setiap kelompok, siswa-siswa saling memberikan pendapatnya untuk memecahkan masalah yang dihadapi.

Penerapan model pembelajaran ROPES melibatkan siswa secara aktif (Sinaga \& Simarmata, 2014). Proses pembelajaran yang menggunakan simulasi dan menggunakan LKS berarti siswa diberikan tanggung jawab untuk mendapatkan konsep sendiri atau memecahkan masalah secara mandiri (Sanjaya, 2008). Hal ini dapat melibatkan siswa untuk mengonstruksi pengetahuan dari materi pembelajaran yang diberikan (Eggen \& Kauchak, 2012). Siswa secara mandiri memecahkan masalah dengan mendengarkan arahan dan bimbingan dari 
guru sehingga dalam proses pembelajaran siswa mampu memecahkan permasalahan.

Penerapan model pembelajaran konvensional menempatkan siswa sebagai obyek. Siswa kurang mendapatkan kesempatan dalam menemukan suatu konsep, memberikan pendapat dan tanggapan maupun menimbulkan pemikiran kreatif pada siswa tentang sebuah permasalahan yang didapat dalam pembelajaran. Dengan demikian dapat berpengaruh terhadap rendahnya nilai prestasi belajar siswa pada bahan ajar yang didapat. Berdasarkan hasil tes nilai prestasi belajar, menunjukkan bahwa tingkat prestasi belajar siswa pada kelas kontrol yang belajar dengan pembelajaran model konvensional lebih rendah dengan perbandingan siswa kelas eksperimen dengan menggunakan pembelajaran model ROPES.

\section{SIMPULAN}

Sesuai dengan data dan hasil penelitian dan pembahasan yang sudah disebutkan sebelumnya tentang pengaruh pembelajaran model ropes terhadap keaktifan dan prestasi belajar fisika siswa kelas VII SMP PGRI 6 Malang, maka dapat disimpulkan sebagai berikut :1) Terdapat perbedaan keaktifan belajar siswa yang menggunakan pembelajaran model ropes dengan pembelajaran model konvensional; 2) Terdapat perbedaan nilai prestasi belajar siswa yang menggunakan pembelajaran model ROPES dengan pembelajaran model konvensional, dan 3) Terdapat interaksi antara pembelajaran model ropes terhadaap keaktifan belajar and prestasi belajar siswa.

\section{REFERENSI}

Anam, K. (2015). Pembelajaran Berbasis Inkuiri. Yogyakarta: Pustaka Pelajar.

Arikunto, S. 2012. Dasar-dasar Evaluasi Pendidikan. Jakarta: Bumi Aksara.

Eggen, P. \& Kauchak, D. (2012). Strategi dan Model Pembelajaran. Mengejar Konten dan Keterampilan Berfikir. Jakarta: PT Indeks Permata Puri Media.
Faizi. (2013). Penerapan Penemuan Terbimbing Dengan Teknik Think Pair Share (TPS) Untuk Meningkatkan Aktivitas Dan Hasil Belajar Matematika Siswa Kelas VII C SMP Negeri 5 Kota Bengkulu. Skripsi tidak diterbitkan. Universitas Bengkulu.

Nurhadi. (2004). peningkatan aktivitas dan hasil belajar siswa kelas viii A MTs Darul Ulum Purwogondo Jepara Semester. Yogyakarta.

Rusman. (2014). Model-Model Pembelajaran. Depok: Rajagrafindo Persada.

Wahyuni, E. E. (2006). Model Pembelajaran Ropes Disertai Media Audiovisual Terhadap Aktivitas Dan Hasil Belajar Siswa Pada Pembelajaran Fisika di MAN 1 Jember. Skripsi tidak diterbitkan. Universitas Negeri Jember.

Sanjaya, W. (2008). Strategi Pembelajaran. Jakarta: Kencana Prenada.

Sholikhah, S. (2016). Pengaruh Model Pembelajaran Learning Cycle $7 E$ Dan Minat Belajar Terhadap Prestasi Belajar IPA Siswa kelas VII MTs Negeri Bojonegoro II Padangan Tahun2015/2016. Skripsi tidak diterbitkan. Univesitas Kanjuruhan Malang.

Sinaga \& Simarmata. (2014). pengaruh model pembelajaran ropes (review, overview, presentation, exercise, summary) berbantuan audio visual terhadap hasil belajar siswa pada materi kalor di kelas $x$ semester ii sma $n 11$ medan. Jurnal INPAFI. Vol. 2: 95-101.

Slameto. (2010). Belajar dan faktor-faktor yang Mempengaruhinya. Jakarta: Rineka Cipta.

Sudjana, N. (2011). Penilaian Hasil Proses Belajar Mengajar. Bandung: Remaja Rosdakarya.

Sugiyono. (2010). Metode Penelitian Pendidikan Pendekatan Kuantitatif, Kualitatif, Dan R\&D. Bandung Alfabeta. 
Suprijono, A. (2010). Cooperative Learning Teori dan Aplikasi PAIKEM.

Yogyakarta: Pustaka Pelajar.

Syaiful, S. (2005). Metode Penelitian, Teori dan Aplikasi. Yogyakarta: Gitanyali. 